\title{
Antibiotic and Heavy Metal Resistance of Escherichia coli Strains Isolated from the Seve Dam, and Konak Pond, Kilis, Turkey
}

\section{Hatice Aysun MERCIMEK TAKCI ${ }^{*}{ }^{\mathbb{D}}$, Sevil TOPLAR ${ }^{2}$, Melis SUMENGEN ÖZDENEFE $^{3} \mathbb{D}$}

${ }^{1}$ Kilis 7 Aralık University, Faculty of Arts and Sciences, Department of Molecular Biology and Genetics, 79000 Kilis, Turkey

${ }^{2}$ Kilis 7 Aralık University, Institute of Science and Technology, 79000 Kilis, Turkey.

${ }^{3}$ Near East University, Faculty of Engineering, Department of Biomedical Engineering, Nicosia, North Cyprus via Mersin 10 Turkey.

*Corresponding Author: mersimek@hotmail.com

Received 29 September 2020; Accepted 19 November 2020; Release date 01 June 2021.

How to Cite: Mercimek Takc1, H. A., Toplar, S., \& Sumengen Özdenefe, M. (2021). Antibiotic and heavy metal resistance of Escherichia coli strains isolated from the Seve Dam, and Konak Pond, Kilis, Turkey. Acta Aquatica Turcica, 17(2), 290297. https://doi.org/10.22392/actaquatr.801564

\begin{abstract}
Pollution of surface waters with coliform bacteria having antibiotic and heavy metal resistance has become an increasing public health risk. For this reason, antibiotic and heavy metal resistance profiles of fecal microorganisms in surface water samples collected from two different points (Seve Dam and Konak Pond, Kilis, Turkey) were analyzed in this study. The various physicochemical parameters such as $\mathrm{pH}$, Temperature, Total Dissolved Solids (TDS), Electrical Conductivity (EC) of samples were also examined. The total coliform load in each sample was $>1100$ (MPN)/100 mL. As fecal indicator microorganisms, 21 Escherichia coli strains were isolated from sampling points. Despite the high coliform contamination, the multiple antibiotic resistance (MAR) index of E. coli was recorded as 0.187 . The multiple heavy metal resistance (MHMR) index (0.202) was remarkably higher than the MAR value. Most isolates showed minimal inhibition concentrations (MIC) in the range of $25-1.600 \mu \mathrm{g} / \mathrm{mL}$ based on concentrations of heavy metals. These results indicate that surface waters may be discharge points of industrial and domestic wastewaters
\end{abstract}

Keywords: Antibiotic, Heavy metal resistance, Coliform pollution, Water quality.

Konak Göleti ve Seve Barajı’ndan, (Kilis, Türkiye) izole edilen Escherichia coli suşlarının antibiyotik ve ağır metal dirençliliği

Özet

Antibiyotik ve ağır metal dirençliliği gösteren koliform bakterilerle yüzeysel suların kirliliği artan bir halk sağlığı riski oluşturmaktadır. Bu nedenle, çalışmamızda Kilis İlinde iki farklı bölgeden (Seve Barajı ve Konak Göleti) toplanan yüzey suyu örneklerindeki fekal bakterilerin antibiyotik ve ağır metal dirençlilik profilleri araştırılmıştır. Örneklerin pH, sıcaklık, toplam çözünmüş katı madde (TDS) ve elektrik iletkenlik (EC) gibi çeşitli fizikokimyasal değişkenleri incelenmiştir. Her örnekteki total koliform sayısı >1100 (EMS)/100 mL'dir. Örnek noktalarında fekal kirliliğin indikatörü olarak 21 Escherichia coli suşu izole edilmiştir. Yüksek koliform kirliliğine karşın, E. coli izolatlarının çoklu antibiyotik direnç (ÇAD) indeksi 0.187 olarak kaydedilmiştir. Çoklu ağır metal direnç (ÇAMD) indeksi (0.202) ise çoklu antibiyotik direncinden yüksek bulunmuştur. Çoğu izolatın $25-1.600 \mu \mathrm{g} / \mathrm{mL}$ aralığında minimum inhibibe edici konsantrasyon gösterdiği belirlenmiştir. Bu sonuçlar yüzey sularının endüstriyel ve evsel atıksuların etkisi altında olabileceğini göstermektedir.

Anahtar Kelimeler: Antibiyotik, Ağır metal direnç, Koliform kirliliği, Su kalitesi

\section{INTRODUCTION}

Increased interaction between human and domestic animals adversely affects wildlife and ecosystem such as soil and surface waters (Hacioglu et al., 2015). Especially surface waters often are polluted with waste products of industrial, hospitals, and pharmaceutical companies. This is caused that surface waters are suitable environmental media for the growth of fecal coliform bacteria. The occurrence of coliform bacteria (Escherichia coli, Klebsiella spp., Enterobacter spp., Citrobacter spp. and Serratia spp.) in the water system such as brackish and fresh waters is indicated to contamination originated by human and animal feces (Dobrijević et al., 2017; Akkan and Topkaraoğlu, 2019). 
As well as fecal contamination in water, the antibiotic resistance of bacterial pathogens as a factor of disease emergence is a serious and growing problem around the world (World Health Organization, [WHO] 2018; Eduardo-Correia et al., 2020). Antibiotics have been spread to the environment and pose a threat to the human society and ecosystems due to their large-scale usage in human healthcare, livestock management, and aquaculture ( $\mathrm{Li}$ et al., 2020). However, most of the antibiotics performed to target organisms are poorly absorbed and released via feces or urine in the form of metabolites (Heuer et al., 2008). Though some of the excreted antibiotics and their metabolites can be degraded by abiotic and biotic pathways, the continuous-release may be caused to pseudo persistent antibiotics in the aquatic environments. (Wang et al., 2018). The untreated antibiotic wastes in the aquatic environments are contributed to the proliferation of bacteria having multiple antibiotic resistances increased virulence (Matyar et al., 2014; Akkan, 2017).

Metal contamination of aquatic environments often originates from mining activities, wood processing, shipping, dredging, urbanization, agrochemicals, and industrial processes (Jacquiod et al., 2018). Heavy metals toxicity and accumulation in surface waters are constituted a serious ecological hazard on wildlife and public health (Jie et al., 2016; Uncumusaoğlu et al., 2016). Akkan et al., (2011) had shown that an important proportion of gram-negative bacteria isolated from seawater contaminated with hospital waste discharge was resistant to cephalosporins and this situation carries a potential risk for public health. Tee and Najjah (2011) indicated that overdosing on antibiotics and chemical agents in prophylaxis may also be induced by antibiotic-heavy metal resistant bacteria. Similarly, George and Wan (2019) reported that antibiotic resistance linked to mobile genetics elements is co-occurred with heavy metal resistance in many bacteria. Bacterial metal resistance is associated with the precipitation of metals, presence of negatively charged groups in extracellular polymeric substances (EPSs), energy-dependent metal efflux systems, and metal volatilization via methyl or ethyl group addition (Matyar et al., 2014; Le and Yang, 2019).

This study is aimed to investigate physicochemical properties, the level of coliform pollution, the presence of Escherichia coli, antibiotic and heavy metal resistance of water-borne E. coli in surface waters obtained from the Seve Dam and Konak Pond, Kilis, Turkey.

\section{MATERIAL AND METHODS}

\section{Collecting surface water samples}

Surface waters were sampled in June 2020 from the Seve Dam and Konak Pond in Kilis. The geographic coordinates of the sampling sites were $37^{\circ} 14^{\prime} 46.1 " \mathrm{E}, 36^{\circ} 45^{\prime} 01.0^{\prime \prime} \mathrm{N}$ (Site 1) and $37^{\circ} 13^{\prime} 30.2^{\prime \prime} \mathrm{E}, 36^{\circ} 46^{\prime} 24.2^{\prime \prime} \mathrm{N}$ (Site 2) (Fig. 1). Surface samples were collected by using $250-\mathrm{mL}$ sterile bottles in accordance with APHA 2005. All samples were transported to the laboratory in an icebox and processed within $2-4 \mathrm{~h}$.

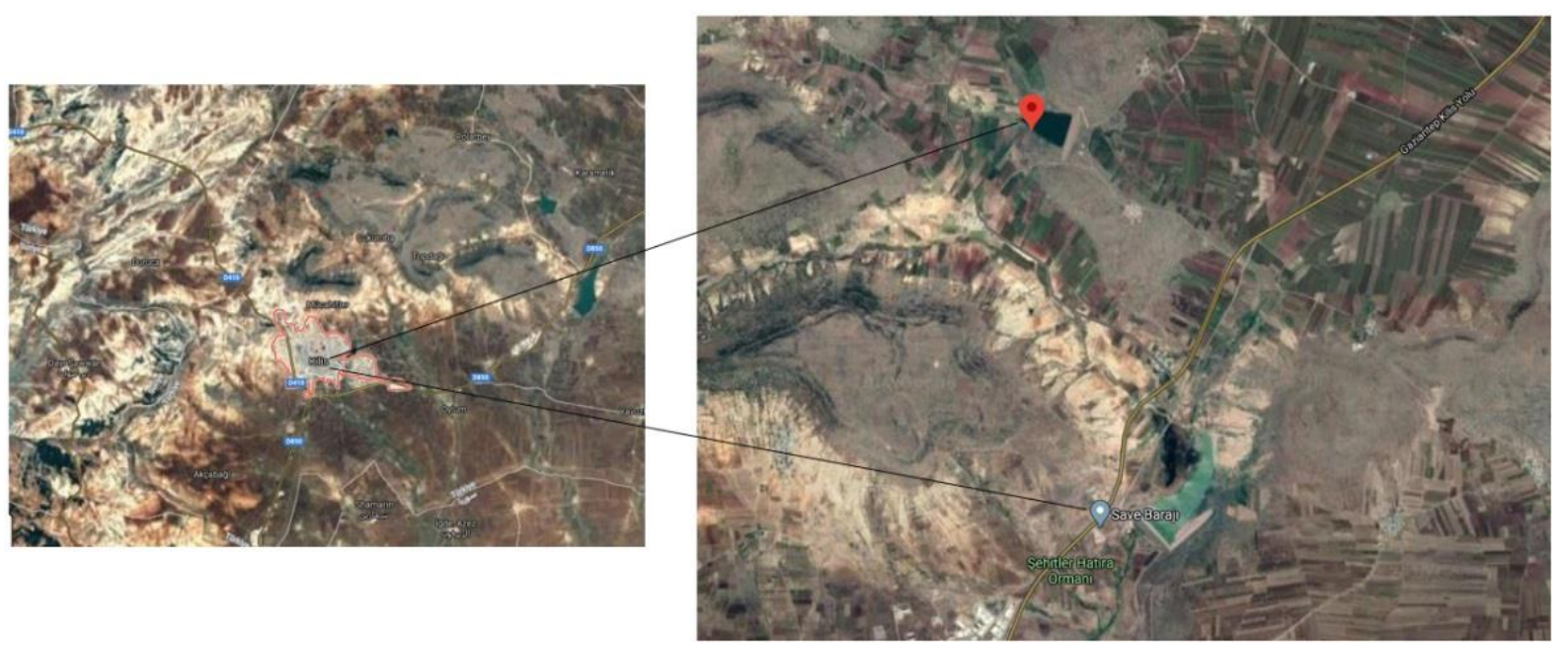

Figure 1. Sampling location 


\section{Physicochemical properties of samples}

Physicochemical properties such as the total dissolved solids (TDS), electrical conductivity (EC), $\mathrm{pH}$ and temperature of the surface water samples taken from 2 different sites were determined using HI 9812-5 Portable $\mathrm{pH} / \mathrm{EC} / \mathrm{TDS} /{ }^{\circ} \mathrm{C}$ meter.

\section{Bacteriological analyses}

The level of coliform pollution of water samples was analyzed by the most probable number (MPN) method. Serial dilution of samples was inoculated including Lauryl Sulfate Broth (LST, Merck) in tubes and incubated at $37^{\circ} \mathrm{C}$ for $24-48 \mathrm{~h}$. Following incubation, bacterial proliferation and gas bubbles collected in the inverted Durham tube present in tubes were examined. The presence of gas in tubes is showed to use the lactose in the medium by coliforms. In water samples, the number of total coliforms was calculated by counting the tubes giving positive reaction and comparing with standard statistical tables. For screening fecal coliform, $100 \mu \mathrm{L}$ of positive tubes was transferred into the fresh LST and incubated at $44.5^{\circ} \mathrm{C}$ for $24-48 \mathrm{~h}$. The gas formation in Durham tubes after incubation is revealed to the presence $E$. coli in surface water samples.

Endo $\mathrm{C}$ agar for isolation E. coli strains was used. $100 \mu \mathrm{L}$ of the fecal coliform positive cultures was inoculated on Endo $\mathrm{C}$ agar and incubated at $37^{\circ} \mathrm{C}$ for $24-48 \mathrm{~h}$. Subsequently, colony colors of $E$. coli were observed. On Endo $\mathrm{C}$ if $E$. coli is grown, a distinctive metallic green sheen will have occurred. Isolated colonies were identified by applying morphological (Gram staining and cell morphology) and standard microbiological (indole, methyl red, voges proskauer, citrate, and MUG (4Methylumbelliferyl $\beta$-D-Glucuronide) agar test systems) procedures.

\section{Antibiotic and Heavy Metal Resistance}

Antibiotic resistance test was carried out on Mueller Hinton Agar (MHA) by Kirby-Bauer disc diffusion assay according to the Clinical Laboratory Standard Institute (CLSI) guidelines (Bauer et al., 1966). 16 different commercial antibiotic including Ampicillin (AMP; $10 \mu \mathrm{g}$ ), Cefazolin (CZ; $30 \mu \mathrm{g}$ ), Cefepime (FEB; $30 \mu \mathrm{g}$ ), Cefixime (CFM; $5 \mu \mathrm{g}$ ), Cefoperazone (CEP; $75 \mu \mathrm{g}$ ), Ceftizoxime (ZOX; 30 $\mu \mathrm{g}$ ), Chloramphenicol (C; $30 \mu \mathrm{g})$, Clindamycin (CD; $2 \mu \mathrm{g}$ ), Erythromycin (E; $15 \mu \mathrm{g})$, Gentamicin (GEN; $10 \mu \mathrm{g}$ ), Imipenem (IMP; $10 \mu \mathrm{g}$ ), Meropenem (MRP; $10 \mu \mathrm{g}$ ), Metronidazole (MT; $5 \mu \mathrm{g}$ ), Streptomycin (S; $10 \mathrm{mcg}$ ), Tetracycline (TE; $30 \mathrm{mcg}$ ) and Trimethoprim (TR; $5 \mu \mathrm{g}$ ) were tested for all strains. The turbidity of the overnight bacterial culture was adjusted to 0.5 McFarland standard reference range. Following the inoculation, the plates were incubated at $37^{\circ} \mathrm{C}$ for $12-24 \mathrm{~h}$. Then, the diameter of the inhibition zone was measured and the results were evaluated as susceptible, intermediate resistant, or resistant by comparing to CLSI standard results (Table 1).

Table 1. Zone diameter interpretive criteria for testing antibiotic resistance (in terms of $\mathrm{mm}$ )

\begin{tabular}{lccc}
\hline \hline Standard antibiotics & Susceptible $(\mathbf{S})$ & Intermediate $(\mathbf{I})$ & Resistant $(\mathbf{R})$ \\
\hline Ampicillin & $\geq 17$ & $14-16$ & $\leq 13$ \\
Cefazolin & $\geq 23$ & $20-22$ & $\leq 19$ \\
Cefepime & $\geq 18$ & $15-17$ & $\leq 14$ \\
Cefixime & $\geq 19$ & $16-18$ & $\leq 15$ \\
Cefaperazone & $\geq 21$ & $16-20$ & $\leq 15$ \\
Ceftizoxime & $\geq 25$ & $22-24$ & $\leq 21$ \\
Chloramphenicol & $\geq 18$ & $13-17$ & $\leq 12$ \\
Clindamycin & $\geq 21$ & $15-20$ & $\leq 14$ \\
Erythromycin & $\geq 23$ & $14-22$ & $\leq 13$ \\
Gentamicin & $\geq 15$ & $13-14$ & $\leq 12$ \\
Imipenem & $\geq 23$ & $20-22$ & $\leq 19$ \\
Meropenem & $\geq 23$ & $20-22$ & $\leq 19$ \\
Metronidazole & $\geq 21$ & $16-21$ & $\leq 16$ \\
Streptomycin & $\geq 15$ & $12-14$ & $\leq 11$ \\
Tetracycline & $\geq 15$ & $12-14$ & $\leq 11$ \\
Trimethporim & $\geq 16$ & $11-15$ & $\leq 10$ \\
\hline \hline
\end{tabular}


E. coli ATCC 25922 was used as the control for antibiotic and heavy metal resistance tests. The multiple antibiotic resistances (MAR) index of E. coli strains was calculated based on method declared by Krumperman (1983). The following formula was used:

MAR index $=\mathrm{X} /(\mathrm{YxZ})$, where $\mathrm{X}$ is the total of antibiotic resistance cases, $\mathrm{Y}$ is the total antibiotic tested and $\mathrm{Z}$ is total isolates. A MAR index value $\leq 0.20$ is observed that antibiotics are seldom or never used, whereas value $>0.2$ is indicated that bacteria isolates are exposed to the antibiotics (Hacioglu et al. 2015).

The minimal inhibitory concentration (MIC) for four heavy metals against $E$.coli isolates was tested. Heavy metal resistance of E. coli strains was detected by using Nutrient Agar (Merck) supplemented with concentrations ranging from 25 to $3.200 \mu \mathrm{g} / \mathrm{mL}$ of $\mathrm{Cd}^{+2}, \mathrm{Cu}^{+2}, \mathrm{Mn}^{+2}$ and $\mathrm{Pb}^{+2}$. The metals were used as $\mathrm{CdCl}_{2}, \mathrm{CuSO}_{4} \cdot 5 \mathrm{H}_{2} \mathrm{O}, \mathrm{MnCl}_{2} \cdot 4 \mathrm{H}_{2} \mathrm{O}$ and $\left(\mathrm{CH}_{3} \mathrm{COO}\right)_{2} \mathrm{~Pb} .3 \mathrm{H}_{2} \mathrm{O}$. Multiple heavy metal resistance index (MHMR) was calculated as defined above MAR index formula.

\section{RESULTS and DISCUSSION}

Physicochemical parameters of Seve Dam and Konak Pond surface waters are shown in Table 2. The $\mathrm{pH}$ values of the present study were within the standard limit (6.5-8.5) of Quality Criteria of Continental Surface Water Resources, Turkey.

Table 2. Physicochemical parameters of surface water samples

\begin{tabular}{cccc}
\hline \hline & Site 1 & Site 2 & $\begin{array}{c}\text { Standard Limit } \\
\text { (25730 Regulations, 2015 } \\
\text { and WHO, 2008). }\end{array}$ \\
\hline pH & 8.2 & 8.2 & $6.5-8.5$ \\
Temperature & $25^{\circ} \mathrm{C}$ & $25^{\circ} \mathrm{C}$ & $\leq 25^{\circ} \mathrm{C}$ \\
TDS $(\mathbf{m g} / \mathbf{L})$ & 190 & 170 & max. 500 \\
EC $(\boldsymbol{\mu S} / \mathbf{c m})$ & 390 & 350 & $<400$ \\
\hline \hline
\end{tabular}

These values of samples are revealed to the surface waters of Kilis were alkaline. This may be explained to discharge the industrial and agricultural effluents including alkali into the water sources. The alteration of water temperature such as increase, decrease or fluctuation can be caused to the slowdown, speedup, and/or stop together of metabolic activities. Because of this, water temperature is an important factor that affected the biological activity of aquatic organisms and the variety of aquatic life (Jannat et al., 2019). The temperature of water samples was determined as $25^{\circ} \mathrm{C}$ (Table 2) and this was an acceptable limit $(\leq 25)$ according to surface water quality criteria of Turkey. TDS concentrations of the water samples were in the range of 170 to $190 \mathrm{mg} / \mathrm{L}$, within the maximum allowable value $(500 \mathrm{mg} / \mathrm{L}$ ) of the World Health Organization (WHO 2008). Electrical conductivity (EC) related to the concentration of ions in the water is a measure of passing electrical flow. EC values of water samples were lower than $400 \mu \mathrm{S} / \mathrm{cm}$ which was the standard limit $(<400)$ quality criteria of Turkey. Bulbul and Camur Elipek (2017) revealed the water temperature, $\mathrm{pH}$ values, and electrical conductivity of Meric River (Edirne, Turkey) were ranged between $4.5-22^{\circ} \mathrm{C} ; 7.4-8.4 ; 172-798 \mu \mathrm{S} / \mathrm{cm}$, respectively. Similar results were acquired by Hulyar and Altug (2020) who stated that $\mathrm{pH}$ values and temperature of Cirpici River (Istanbul, Turkey) and its flowing areas recorded between 6.0-8.38 and $10.3-29.5^{\circ} \mathrm{C}$. The other study in Pindare River (Brazil) predicated that $\mathrm{pH}$, temperature, TDS, and EC values in the three sampling points in the dry season were $7.06-8.13 ; 24-27^{\circ} \mathrm{C} ; 140.66-185 \mathrm{mg} / \mathrm{L}$ and 213-363.33 $\mu \mathrm{S} / \mathrm{cm}$, respectively (Muniz et al., 2020).

The counts of total coliform bacteria in the water samples taken from the Seve Dam and Konak Pond were $>1100$ MPN per $100 \mathrm{~mL}$ of sample. E. coli strains isolated from tubes giving positive reaction at $44.5^{\circ} \mathrm{C}$ for $24-48 \mathrm{~h}$. All isolates showing Gram-negative bacilli morphological character were identified by biochemical test (indole, methyl red, voges proskauer, citrate, and MUG test systems). These isolates giving positive reaction were evaluated as E. coli. A total of $21 \mathrm{E}$. coli isolates were obtained from Site 1 (14 strains) and Site 2 (7 strains), respectively. Based on the WHO (2017) and TS 266 (2005) guidelines, water resources used for drinking water and water intended for human consumption should not contain total and fecal coliform bacteria $(0 / 100 \mathrm{~mL})$. Bacteriological findings in this study are clearly emphasized to discharge of household and industrial wastewater 
systems into the dam without control. This anthropogenic activities may affect the metabolic activities in aquatic ecosystems and the biodiversity of aquatic life.

In many surface water studies, it is stated to domestic and industrial originated bacterial pollution (Kayis et al., 2017; Hulyar and Altug, 2020). Similarly, total coliform levels in samples obtained from three ponds of Nigeria were declared to range from 120 to $1200 \mathrm{MPN}$ per $100 \mathrm{~mL}$ and the presence of fecal coliform was reported (Douglas and Isor, 2015). For Karasu River (Sinop, Turkey), the maximum total and fecal coliform level was reported as $240 \mathrm{MPN} / 100 \mathrm{~mL}$ in June (Avsar, 2018).

In addition to bacteriological load, several papers screened the antibiotic resistance potentials of bacteria isolated from surface waters (Ozgumus et al., 2007; Toroglu and Toroglu, 2009; Akturk et al., 2012). As shown in Figure 2, the results of the antibiotic susceptibility test indicated that $100 \%$ of the E. coli strains isolated were resistant to clindamycin, erythromycin, and metronidazole. However, none of the isolates developed any resistance to $56.25 \%$ of standard antibiotics (against cefepime, cefixime, cefoperazone, ceftizoxime, chloramphenicol, gentamicin, imipenem, meropenem, and trimethoprim).

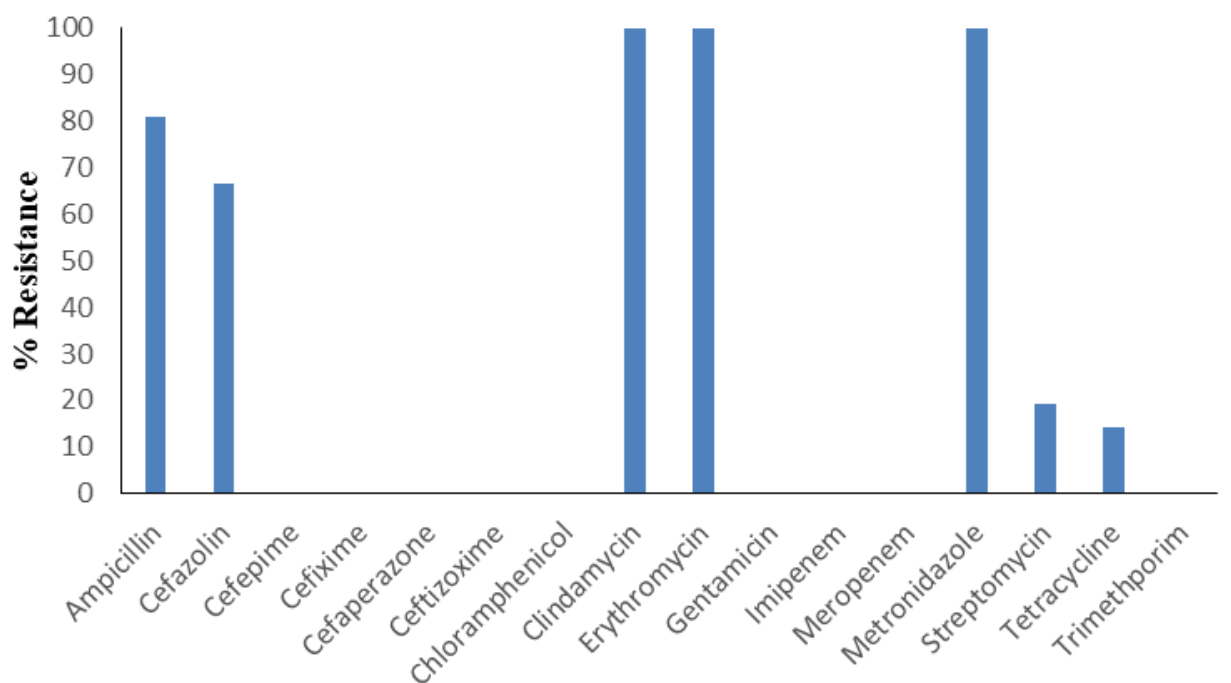

Tested Standard Antibiotics

Figure 2 Antibiotic susceptibility profiles of $E$. coli isolates

Among screening 16 standard antibiotics, isolates were determined to be intermediate resistance against ampicillin (80.95\%), cefazolin (66.67\%), streptomycin (19.04\%), and tetracycline (14.28\%). E. coli ATTC 25922 showed only resistance to clindamycin and metronidazole antibiotics, while it had the intermediate resistance to erythromycin, ampicillin, and cefazolin. Kurekci et al., (2017) found that $E$. coli strains recovered from the Asi River (Turkey) showed resistance against extendedspectrum $\beta$-lactam antibiotics. In coliforms isolated from ten rivers in the northern region of Turkey, Ozgumus et al., (2009) notified resistance to ampicillin, streptomycin, trimethoprim, tetracycline, and chloramphenicol in contrast to our susceptibility results. A previous study reported the high coliform pollution ( $>1100 \mathrm{MPN} / 100 \mathrm{~mL}$ ) in Aksu River, (Turkey) noted that $42.2 \%$ of E. coli strains were resistant against $\beta$-lactam antibiotics (Toroglu et al., 2005). Also, Akkan et al., (2019) reported that TC, FC, and FS rates were determined to $45 \%, 71.66 \%$, and $56.66 \%$, respectively, in the sixty surface water samples collected from Yağlidere Stream, thus this situation indicating bacteriological pollution. The study on the Gram-negative bacteria was isolated from the seawater of Iskenderun Bay showed that antibiotic resistances of 161 isolates were at high percentages for erythromycin: $94.4 \%$, ampicillin: $72.7 \%$, streptomycin: $68.3 \%$, cefazolin:64.6\%, and carboksipeneme: $57.1 \%$ (Akkan et al., 2011).

This revealed to be the antibiotic resistance $18.75 \%$ or 63 cases and intermediary antibiotic sensitive case (11.30\% or 38 cases) of 336 total cases. The recorded MAR index value was 0.187. Similar to this study result, the low MAR index for E. coli isolates in Kucukcekmece Lagoon (Istanbul, Turkey) was determined as 0.14 (Kimiran-Erdem et al., 2015). A recent study carried out in Karasu River; MAR index values of isolated E. coli strains were in range from 0.4-0.7 (Avsar, 2018) 
which these values higher than the result of this study. In a study conducted on the Enterobacteriaceae isolated from the Giresun coast, the researchers found that $91 \%$ of all isolates' multiple antibiotic resistance (MAR) index values were higher than 0.2 (Akkan and Mutlu, 2016). Matyar et al. (2014) reported that MAR index ranged from 0.2 to 0.81 for Gram-negative bacteria isolated Seyhan River and Seyhan Lake Dam.

All E. coli isolates showed high resistance to lead and manganese heavy metal. Tolerance to the highest MIC of this heavy metal was found as $1600 \mu \mathrm{g} / \mathrm{mL}$. This value of copper was $400 \mu \mathrm{g} / \mathrm{mL}$. All isolates were observed to sensitive against cadmium heavy metal. MHMR index of $E$. coli strains was calculated as 0.202. For E. coli ATCC 25922, it was observed to the different tolerance against $\mathrm{Pb}^{+2}$ $(25-1600 \mu \mathrm{g} / \mathrm{mL}), \mathrm{Cu}^{+2}(25-200 \mu \mathrm{g} / \mathrm{mL})$ and $\mathrm{Mn}^{+2}(25-1600 \mu \mathrm{g} / \mathrm{mL})$. Trends in heavy metal resistance of $E$.coli strains were $\mathrm{Pb}=\mathrm{Mn}>\mathrm{Cu}$ depending on concentrations. Similarly, Icgen and Y1lmaz (2014) expressed the resistance to heavy metals including $\mathrm{Cu}^{+2}, \mathrm{Mn}^{+2}$, and $\mathrm{Pb}^{+2}$ in Kizılırmak River isolates. Matyar et al. (2008) found that the heavy metal resistance of İskenderun Bay (Turkey) isolates was in the order of $\mathrm{Cd}>\mathrm{Cu}>\mathrm{Pb}>\mathrm{Cr}>\mathrm{Mn}$. Similarly, another study of Matyar et al., (2009) showed that the heavy metal resistance of fish samples collected from Iskenderun Bay were; for gill $\mathrm{Cd}>\mathrm{Cu}>\mathrm{Mn}>\mathrm{Cr}=$ $\mathrm{Pb}$, and for intestine: $\mathrm{Cd}>\mathrm{Cu}>\mathrm{Cr}>\mathrm{Mn}=\mathrm{Pb}$. Sipahi et al., (2013) reported that 134 isolates of the Enterobacteriace were resistant to copper while manganese $61.94 \%$ and lead $46.27 \%$ were resistant.

Ciftci Turetken et al. (2019) informed the frequency of bacterial antibiotics and heavy metal resistance and bioindicator bacteria in the water samples taken from Sapanca Lake. They notified that the highest bacterial resistance was recorded as $88.10 \%$ against ampicillin in a total of resistant Gramnegative strains. The heavy metal resistance against $\mathrm{Cu}$ and $\mathrm{Cd}$ was detected as $52.38 \%$ and $26.19 \%$, respectively. This result showed that the lowest resistance property was observed against cadmium. Benhalima et al. (2020) investigated the determination of copper and cadmium concentrations and heavy metal-resistant bacteria identification in water samples obtained from Seybouse River, Algeria. The $\mathrm{pH}$ of the water samples was alkaline. The MIC value of E. coli KZ1 isolate was determined as $400 \mu \mathrm{g} / \mathrm{mL}$ and $200 \mu \mathrm{g} / \mathrm{mL}$ for copper and cadmium, respectively. Their results are similar to the results of this study especially in terms of copper value. Maal-Bared et al. (2013) noted that the distribution of antibiotic-resistant Escherichia coli and E. coli $\mathrm{O} 157$ isolated from water in an intensive agricultural watershed in Elk Creek, British Columbia. Both E. coli and E. coli O157 isolates showed the highest frequency of resistance to tetracycline, ampicillin, streptomycin, respectively. Their results are similar to the results of this study in terms of ampicillin value. On the other hand, tetracycline (14.28\%) and streptomycin (19.04\%) values are not similar. In contrast to the highest resistance values for tetracycline and streptomycin, the results showed that sensitive values for this study.

Even though isolated E. coli strains had a low MAR index (0.187), the study findings indicated the presence of high coliform contamination and fecal pollution in the Seve Dam and Konak Pond water samples. Multiple antibiotic resistance (MAR) analysis is a practice method performed to differentiate sources of fecal pollution. In brief, MAR patterns of coliform and/or fecal coliform strains may be informed of the types (human or animal origin) of pollution in waters. Kimiran Erdem et al. (2015) reported that the low MAR index was observed in E. coli of animal origin. According to this literature, it is clear that $E$.coli contamination in Seve Dam and Konak Pond originated waste of animals on which antibiotics were seldom or never used. The MHMR index $(0.202)$ of $E$. coli strains was remarkably higher than the MAR index value. This MHMR value is indicated that marine environments such as Seve Dam and Konak Pond may be the discharge point with the heavy metal load from originated from various industrial facilities. This heavy metal tolerance level of $E$. coli isolates is showed that they could be used in bioremediation research of metal-contaminated aquatic sites.

\section{CONCLUSION}

In a conclusion, a high level of MHMR index and high counts of coliform bacteria is indicated that the Seve Dam and Konak Pond under the influence of human-sourced pollution as a potential reservoir of animal and industrial wastes. Therefore, the uncontrolled discharges and overloaded into Pond and Dam should be prevented to provide sustainable usage of these water sources in Kilis, Turkey. 


\section{REFERENCES}

Akkan, T. (2017). Antibiotic resistance case study: Enterobacteriaceae isolated from Batlama Creek in Giresun, Turkey. Turkish Journal of Agriculture - Food Science and Technology, 5(8), 969-972.

Akkan, T, Kaya, A., \& Dinçer, S. (2011). Hastane atık sularıyla kontamine edilen deniz suyundan izole edilen gram negatif bakterilerin sefalosporin grubu antibiyotiklere karşı direnç düzeyleri. Türk Mikrobiyoloji Cemiyeti Dergisi, 4(1), 18-21.

Akkan, T., Mehel, S., \& Mutlu, C. (2019). Determining the level of bacteriological pollution level in Yağlidere Stream, Giresun. LimnoFish, 5(2), 83-88.

Akkan, T., \& Mutlu, C. (2016). Determination of antibiotics resistance levels in Enterobacteriaceae isolated from Giresun Coasts. Turkish Journal of Agriculture-Food Science and Technology, 4(8), 640-650.

Akkan, T., \& Topkaraoğlu, T. (2019). Determination of antibiotic resistance levels of Escherichia coli isolates obtained from freshwater sources: Batlama Creek. Journal of Anatolian Environmental and Animal Sciences, 4(3), 539-544.

Akturk, S., Dincer, S., \& Toroglu, S. (2012). Determination of microbial quality and plasmid-mediated multidrug resistant bacteria in fountain drinking water sources in Turkey. Journal of Environmental Biology, 33(6), 1127-1136.

Avsar, C. (2018). Measurement of antibiotic resistance of microbial species in the Karasu River (Turkey) using molecular techniques. The Water and Environment Journal, 33, 179-191.

Benhalima, L., Amri, S., Bensouilah, M., \& Ouzrout, R. (2020). Heavy metal resistance and metallothionein induction in bacteria isolated from Seybouse River, Algeria. Applied Ecology and Environmental Research, 18(1), 1721-1737.

Bauer, A.W., Kirby, W.M., Sherris, J.C., \& Turck, M. (1966). Antibiotic Susceptibility Testing by a standardized single disk method. American Journal of Clinical Pathology, 45(4), 493-496.

Bulbul, G., \& Camur-Elipek, B. (2017). Investigation of the effects of domestic waste on aquatic bacterial distribution in the Meric River (Edirne, Turkey). Biologija, 63(3), 256-263.

Ciftci Turetken, P. S., Altug, G., Cardak, M., \& Gunes, K. (2019). Bacteriological quality, heavy metal and antibiotic resistance in Sapanca Lake, Turkey. Environmental Monitoring and Assessment, 191:469.

Dobrijević, D., Trudić, A., Borčić, V., \& Bekut, M. (2017). Antibiotic susceptibility profile of Klebsiella pneumoniae strains isolated from drinking and surface water. Racionalna terapija, IX(1), 1-13.

Douglas, S.I., \& Isor, F.N. (2015). Bacteriological investigation of pond water quality from Ogoniland, Nigeria. IOSR Journal of Environmental Science, Toxicology and Food Technology, 9(2), 36-41.

Eduardo-Correia, B., Morales-Filloy, H., \& Abad, J.P. (2020). Bacteria from the multi-contaminated Tinto River Estuary (SW, Spain) show high multi-resistance to antibiotics and point to Paenibacillus spp. as antibiotic-resistance-dissemination players. Frontiers in Microbiology, 10, 3071.

George, S.E., \& Wan, Y. (2019). Advances in characterizing microbial community change and resistance upon exposure to lead contamination: Implications for ecological risk assessment. Critical Reviews in Environmental Science and Technology, 50(20), 2223-2270.

Hacioglu, N., Gul, C., \& Tosunoglu, M. (2015). Bacteriological screening and antibiotic-heavy metal resistance profile of the bacteria 1solated from some amphibian and reptile species of the Biga Stream in Turkey. The World Academy of Science, Engineering and Technology, 9(4), 422-426.

Heuer, H., Focks, A., Lamshoft, M., Smalla, K., Matthies, M., \& Spiteller, M. (2008). Fate of sulfadiazine administered to pigs and its quantitative effect on the dynamics of bacterial resistance genes in manure and manured soil. Soil Biology and Biochemistry, 40(7), 1892-1900.

Hulyar, O., \& Altug, G. (2020). The Bacteriological risk transported to seas by Rivers; the example of Çırpıcı River, Istanbul, TR. International Journal of Environment and Geoinformatics, 7(1), 45-53.

Icgen, B., \& Yilmaz, F. (2014). Co-occurrence of antibiotic and heavy metal resistance in Kizıllrmak River isolates. The Bulletin of Environmental Contamination and Toxicology, 93, 735-743.

Jacquiod, S., Cyriaque, V., Riber, L., Al-Soud, W. A., Gillan, D. C., Wattiez, R., \&Sørensen, S.J. (2018). Longterm industrial metal contamination unexpectedly shaped diversity and activity response of sediment microbiome. Journal of Hazardous Materials, 344, 299-307.

Jannat, N., Mottalib, M.A., \& Alam, M.N. (2019). Assessment of Physicochemical properties of surface water of Mokeshbeel, Gazipur, Bangladesh. Journal of Environmental Science: Current Research, 2, 014.

Jie, S., Li, M., Gan, M., Zhu, J., Yin, H., \& Liu, X. (2016), Microbial functional genes enrichedin the Xiangjiang River sediments with heavy metal contamination. BMC Microbiology, 16, 179.

Kayis Buyukkaya, F., Dincer, S., Matyar, F., Takcı Mercimek, H. A., Sumengen Ozdenefe, M., \& Arkut, A. (2017). An investigation of multiple antibiotic resistance and identification of bacteria isolated from Golbasi and Azaplı Lakes (Adiyaman). Turkish Journal of Agriculture - Food Science and Technology, 5(1), 43-47. 
Kimiran-Erdem, A., Arslan-Aydogdu, E.O., Gurun, S., \& Altun, O. (2015). Determination of multiple antibiotic and heavy metal resistance of the bacteria isolated from the Kucukcekmece Lagoon, Turkey. Polish Journal of Environmental Studies, 24(3), 1077-1084.

Krumpermann, P.H. (1983). Multiple antibiotic resistances indexing of E. coli to identify high-risk sources of fecal contamination of foods. Applied and Environmental Microbiology, 46(1), 165-170.

Kurekci, C., Aydın, M., Yipel, M., Katouli, M., \& Gundogdu, A. (2017). Characterization of extended spectrum $\beta$-lactamase (ESBL)-producing Escherichia coli in Asi (Orontes) River in Turkey. Journal of Water and Health, 15(5), 788-798.

Le, B., \& Yang, S.H. (2019). Biosorption of cadmium by potential probiotic Pediococcus pentosaceus using in vitro digestion model. Biotechnology and Applied Biochemistry, 66(4), 673-680.

Li, X-D., Chen, Y-H., Liu, C., Hong, J., Deng, H., \& Yu, D-J. (2020). Eutrophication and related antibiotic resistance of Enterococci in the Minjiang River, China. Microbial Ecology, 80, 1-13.

Maal-Bared, R., Bartlett, K.H., Bowie, W.R., \& Hall, E.R. (2013). Phenotypic antibiotic resistance of Escherichia coli and E. coli $O 157$ isolated from water, sediment and biofilms in an agricultural watershed in British Columbia. Science of the Total Environment, 443, 315-323.

Matyar, F., Eraslan, B., Akkan, T., Kaya, A., \& Dinçer, S. (2009). İskenderun Körfezi balıklarından izole edilen bakterilerde antibiyotik ve ağır metal dirençliliklerinin araştırılması. Biyoloji Bilimleri Araştırma Dergisi, 2(2), 1-5.

Matyar, F., Kaya, A., \& Dincer, S. (2008). Antibacterial agents and heavy metal resistance in Gram-negative bacteria isolated from seawater, shrimp and sediment in Iskenderun Bay, Turkey. Science of the Total Environment, 407(1), 279-285.

Matyar, F., Gulnaz, O., Guzeldag, G., Mercimek, H. A., Akturk, S., Arkut, A., \& Sumengen Ozdenefe, M. (2014). Antibiotic and heavy metal resistance in Gram-negative bacteria isolated from the Seyhan Dam Lake and Seyhan River in Turkey. Annals of Microbiology, 64, 1033-1040.

Muniz, J.N., Duarte, K., Braga, F.H.R., Lima, N.S., Silva, D.F., Firmo, W.C.A., Batista, M.R.V, Silva, F.M.A.M, Miranda Rita de C.M., \&Silva, M.R.C. (2020). Limnological quality: Seasonality assessment and potential for contamination of the Pindaré River watershed, pre-Amazon region, Brazil. Water, 12(1), 851.

Ozgumus, O. B., Celik-Sevim, E., Alpay-Karaoglu, S., Sandalli, C., \& Sevim, A. (2007), Molecular characterization of antibiotic resistant Escherichia coli strains isolated from tap and spring waters in a coastal region in Turkey. Journal of Microbiology, 45(5), 379-387.

Ozgumus, O. B., Sandalli, C., Sevim, A., Celik-Sevim, E., \& Sivri, N. (2009). Class 1 and Class 2 integrons and plasmid-mediated antibiotic resistance in coliforms isolated from ten Rivers in Northern Turkey. Journal of Microbiology, 47(1), 19-27.

Sipahi, N, Mutlu, C., \& Akkan, T. (2013). Giresun ilinde tüketime sunulan bazi baliklardan izole edilen Enterobacteriaceae üyelerinin antibiyotik ve ağır metal dirençlilik düzeyleri. Glda Dergisi, 38(6), 343349.

Tee, L.W., \& Najiah, M. (2011), Antibiogram and heavy metal tolerance of Bullfrog Bacteria in Malaysia. Open Veterinary Journal, 1(1), 39-45.

Toroglu, E., \& Toroglu, S. (2009), Microbial pollution of water in Golbasi lake in Adiyaman, Turkey. Journal of Environmental Biology, 30, 33-38.

Toroglu, S., Dincer, S., \& Korkmaz, H. (2005). Antibiotic resistance in Gram-negative bacteria isolated from Aksu River in (Kahramanmaras) Turkey. Annals of Microbiology, 55, 229-233.

TS266, Sular-İnsani Tüketim Amaçlı Sular, ICS 13.060. 20. TSE, Ankara, Nisan 2005.

Uncumusaoglu, A.A., Sengul, U., \& Akkan, T. (2016). Environmental contamination of heavy metals in the Yağlıdere Stream (Giresun), Southeastern Black Sea. Fresenius Environmental Bulletin, 25(12), 54925498.

Wang, W., Zhou, L., Gu, X., Chen, H., Zeneg, Q., \& Mao, Z. (2018), Occurrence and distribution of antibiotics in surface water impacted by crab culturing: a case study of Lake Guchenghu, China. Environmental Science and Pollution Research, 25(23), 22619-22628.

World Health Organization [WHO] (2008) Guidelines for drinking water quality. World Health Organization, Geneva, Switzerland.

World Health Organization [WHO] (2017) Guidelines for drinking water quality. World Health Organization, Geneva, Switzerland.

World Health Organization [WHO] (2018) Global Antimicrobial Resistance Surveillance System (GLASS) Report: early Implementation 2016-2017. Geneva.

Yerüstü Su Kalitesi Hakkında KaliteYönetmeliği, 15/04/2015 tarihli ve 29327 sayılı Resmi Gazete. 